\title{
Politics and the practice of planning: the case of Zimbabwean cities
}

Davison Muchadenyika and John J. Williams

\begin{abstract}
Planning is intrinsically a political process. This paper explores how the practice and profession of planning has been affected by politics. Available evidence in Zimbabwe shows that planning is problematized by unsettled national and local politics. However, contested politics can distort the intentions of a sound planning system through advancing political interests of politicians, the ruling elite. Interviews with political actors and planners allow an understanding of how politics has virtually eroded, if not eliminated, a sound planning system. This paper illustrates three dimensions of the relationship between politics and planning. First, the political contestation between the ruling and opposition party has severely undermined planning and its contribution towards coordinated development in cities. Second, planners often succumb to the politics of patronage at the expense of urban residents and town planning principles. Third, the integrity and credibility of planning is seemingly under constant threat from political actors.
\end{abstract}

\section{Introduction}

Planning is defined as a 'self-conscious collective effort to imagine or re-imagine a town, city, urban region or wider territory and to translate the result into priorities for area investment, conservation measures, new and upgraded areas of settlement, strategic infrastructure investments and principles of land-use regulation' (Healey, 2004: 46). Thus, people who conduct planning as a profession are called planners. Planners are people who have received some professional and/or academic training in planning (UN-Habitat, 2009). The conduct of planning depends on planning systems defined as the institutional, legal, regulatory and policy framework, and rationalities, techniques, and ideologies' that inform and guide planning (Kamete, 2009: 898). These planning systems exist globally but differ contextually, based on the socioeconomic-political relations of power in a particular society (Williams, 2000).

In the global South, rapid urbanisation is a common feature, especially in the age of globalisation (Castells, 2012). Urbanisation is managed through a process called planning (UN-Habitat, 2009). In this regard, the way cities are planned and 
managed is therefore fundamental in reaching Sustainable Development Goal (SDG) 11, in particular, in global South cities, where there exist widespread contestations over the planning and management of cities. Through SDG 11, the international community committed itself to 'make cities and human settlements inclusive, safe, resilient and sustainable' by 2030 (UN, 2016). This means, among other things, that cities have to be inclusive, through addressing exclusion from the city and exclusion and segregation in the city (McGranahan, Schensul, \& Singh, 2016). It is in this regard that the conduct of planners and planning approaches are important aspects that contribute to the achievement of SDG 11.

Planning plays a fundamental role in politics and communities subject to existing political regimes (Miller, Sahama, Grace, Wilson, \& Hefferan, 2011). Whilst much attention at the global level has been given to urbanisation; little has been done to understand people who plan and manage cities-planners. Thus, the reality is that 'the role and expertise of planners remains largely invisible and poorly understood' (Dredge \& Coiacetto, 2006: 29). In many instances, planners are subservient to the whims of politics and politicians. Such a reality compromises the independence and integrity of the planning profession.

Planning deals with the configuration of space, though space is highly contentious (Crawford, 2009). In particular, planning engages with the distribution of competing land-uses. Hence, by nature, planning is a conflict generating activity. As such, politicians tend to use power and authority to resolve such conflict often citing 'public interest'. Yet, in some instances, they will be protecting private and personal interests.

This paper focuses on how Zimbabwe's politics affects the profession and practice of planning. Primarily, such a focus is driven by the unsettled nature of the country's politics which has spilled into planning. The political environment in Zimbabwe is also of greater importance in the sense that planning is caught up between two contesting political parties-Zimbabwe African National Union Patriotic Front (ZANU-PF) controlling the national government and the opposition Movement for Democratic Change (MDC) controlling the majority of the urban local authorities. We define politics as formal and informal power relations among actors such as central government, local authorities, political parties, and non-state actors. In addition, the relations between central and local governments have been frosty (Muchadenyika \& Williams, 2016) and therefore, the paper explores the effects of such relations on planners in a highly contested political environment. Further focus is placed on Operation Murambatsvina/Restore Order (OM/RO), a campaign against informal housing and economic activities implemented by the Government of Zimbabwe in 2005. It is through OM/RO that the role of planners came to the fore. In this regard, we explore the public image of the planning profession after such a demolition campaign. 
This paper is structured as follows. After a brief introduction, we provide a critique of how politics and planning have been conceived in extant literature. Thereafter, the paper provides the context of planning and politics in Zimbabwe by indicating key political issues and programmes which influenced planning in situ such as economic structural adjustment programmes, land reform programme, politics of urban control and OM/RO. Next, we explain how data for this paper was collected. The paper moves to a discussion on central-local relations and planners, planners and turbulent politics and OM/RO and the planning profession. The paper concludes by critically assessing the credibility and integrity of planning.

\section{Politics and planning}

Studies on politics and planning have focused on motivations and experiences of planners (Miller et al., 2011); engagement of political actors in spatial planning (Walsh, 2014); planners and politicians (Krumholz, 2001); relations between planners and politicians (Campbell, 2001); politics of difference in planning (Iveson, 2000); planning amidst conflicting societies (Fenster, 2004) and preparing planners to deal with 21st century challenges (Sandercock, 1997) among others.

Planning has been used to portray 'contradictory expressions and belonging of Jews and Palestinians in Israel' (Fenster, 2004: 403). In this case, planning has thus been the main method to which fights over territory and belonging affect the built environment. In post-war Naples, Allum (2003) examines how politicians thwarted the implementation of planning policies such as master plans. In particular, the study argues how private interests of real estate developers were championed by politicians (in return for campaign funds) at the expense of sound town planning.

Politics comes with the exercise of power. Here, power is defined as 'a general matrix of force relations at a given time, in a given society' (Dreyfus and Rabinow, 1983: 186), where 'certain actions structure the field of other possible actions' (Foucault, 1983: 222). In this regard, the practice and profession of planning navigates through power differences. In relation to power and planners, Forester (1989) argues that understanding of power relations by planners helps the planner's decision making. As such, often institutional actors who wield more power tend to dictate planning processes to citizens, based on among others, how and when resources are allocated to planning programmes at grassroots level.

In other sub-Saharan African cities such as Maputo, it has been argued that planning by the state has limited practical impact with non-state actors playing a vital role in shaping urban development (Anderson, Jenkins, \& Nielsen, 2015). Other political actors such as coalitions of the urban poor, community based organisations and civil society organisations have profound impact on how planning shapes the form and structure of cities. Various actors in planning 
processes means among other considerations that planners have to mediate contradictory interests. Moreover, in African cities, urban residents are building cities using a grassroots approach which is contrary to state-led top-down approach to planning (Jenkins, 2013).

Flyvbjerg (1998: 322) argues that in mainstream planning approaches, issues shaping planning 'are defined more by stable power relations than by antagonistic confrontations'. However, in a context where politics and power are both inherently and deeply contested, the conduct of planning becomes tenuous and problematic. In Zimbabwe, tension between central and local governments has revolved around politics associated with land for urban planning and housing development (Muchadenyika, 2015a). In this instance, central government has seemingly usurped the powers of local authorities in determining planning processes and outcomes. On the other hand, local authorities have accused central government of running a parallel urban planning system.

The preceding discussion implies that planning is inherently a political process. Accordingly, it becomes necessary to understand how planners conduct planning in the face of contested politics. Before proceeding to such analysis, the paper provides the context of politics and planning in Zimbabwe and the research methodology used to empirically ground this article.

\section{Politics and planning in Zimbabwe: the context}

In colonial Zimbabwe, planning has been used as an instrument of white settler control and restriction (Potts, 2011). In the post-independence era, planning has mainly been used as an instrument to re-organise the society and economy as well as advancing political interests and objectives of the ruling regime. In essence, planning was and is used as a tool to achieve national development goals as well as political objectives of the ruling elite. However, where planning militates against the interests and objectives of the ruling elite, it is either ignored or rendered useless (Muchadenyika, 2015a).

This section highlights four main issues or programmes which had profound influence on planning in Zimbabwe. First, in the 1990s, the Economic Structural Adjustment Programme (ESAP) resulted in the formal adoption by the government of non-residential activities in residential zones. This is despite that these informal activities existed way before the 1990s. Such non-residential activities (such as medical resource institutions and centres; shops and offices; service industry; warehousing and general maintenance; storage and special industrial use) were permitted through Statutory Instrument 216 of 1994 in residential areas (GoZ, 1994). Urban economies in sub-Saharan Africa were profoundly altered by structural adjustment programmes (Potts, 2006a). In Zimbabwe, structural adjustment programmes also precipitated the sudden rise in informal business, popularly referred to as home industries. In the Zimbabwean context, a home 
industry is 'a site legally zoned for small scale urban informal economic activities' (Kamete, 2004: 120). Home industries were initiated in the 1990 s as part of the government's indigenisation and economic empowerment drive (Jones, 2010). The permission of industrial activities within residential zones meant that planning was supposed to deal with inherent issues emanating from mixedzoning. In brief, structural adjustment programmes challenged and changed the conventional approach to planning.

Second, the Fast Track Land Reform Programme (FTLRP) which started in 2000 has extreme and far reaching implications to coherent urban planning and development in cities (Muchadenyika, 2015a). In fact, the programme reversed planning procedures of layout planning, surveying, servicing and occupation. In other words, the land reform programme transgressed the bureaucratised and technocratic planning system in Zimbabwe. Due to the chaotic manner in which the FTLRP was executed and the politics associated with it, returning to the use of rational planning frameworks faces enormous opposition (Marongwe, 2011). Planners became enmeshed between adhering to planning principles and government's radical objective of land redistribution. In a way, town planning was set aside, as it became difficult to stand in the way of the FTLRP with logical arguments without being a victim of harassment both professionally and physically. The wilful disregard of planning is evidenced by the lack of planning, infrastructure and basic services in most rural and urban settlements which developed during and after the land reform programme (see Matondi, 2012).

Post-200o, the political construction of central government and urban local authorities consists respectively of the ruling party, ZANU-PF and the opposition MDC. Thus, the rivalry between two aforesaid major political parties affected the practice of planning. Planning is a function of governance. However, political contestation turned the planning and governance of urban areas into a political battlefield, characterised by the centralisation of power and ZANU-PF party structures usurping the powers of local authorities (McGregor, 2013). Such a political rivalry meant that parties contested planning processes and outcomes, with the planner caught in the middle. Planners working for local authorities would be accused for advancing or blocking the interests of the opposition party. At the same time, planners working for the government would be seen as 'gatekeepers' for the ruling party.

The institutional arrangement of local government includes the national government (in particular the local government ministry), provincial and local governments (urban and rural local authorities). This is in line with the new Constitution adopted in 2013. Before the 2013 constitution, local government was not constitutionalised and hence the national government intervened and interfered in local authority affairs at will. However, the new dispensation with three tiers of government is still to be implemented as the ruling party, ZANU-PF sees 
devolution as 'a threat to its hold on power' and has 'a strong belief in centralization' (Muchadenyika \& Williams, 2016: 269). As such, despite local authorities being granted the right to run their own affairs in the Constitution, in practice, though, local authorities lack autonomy and real power to plan and govern cities. In fact, the national government manipulates local governments to advance its interests, in particular, those of ZANU-PF (Ibid).

In 2005, the government began a programme called OM/RO mainly 'to deal with crime, squalor and lawlessness, and rebuild and organise urban settlements and small and medium enterprises in a way that would bring dignity, order and prosperity to the stakeholders and the nation at large' (GoZ, 2005: 2). The Operation targeted informalised urban employment and 'illegal' low-income housing solutions in urban areas (Potts, 2006b). The programme also targeted informal business enterprises in cities and towns. Prior, during and after the Operation, there, however, appears to be a total disregard of urban planning principles by both the government and citizenry. Estimates indicate that more than 700,000 people were left homeless by the Operation (UN, 2005). It should also be emphasised that, during the Operation, planning was used to settle political differences (Bracking, 2005). In this case, it seems to be incontrovertible that planning functions as means to silence and crush any potential threat to the ruling elites.

Zimbabwe's urban planning has been described as 'the most established, also the most conservative and least compromising in sub-Saharan Africa' (Kamete, 2007: 154). Thus, it is widely acknowledged that Zimbabwe's planning system is highly technocratic, bureaucratised and out of sync with prevailing socio-economic realities (Potts, 2006b; GoZ, 2009; Kamete, 2006, 2007). Yet, that would significantly change with the politics of urban control. To explain such change, we explore the effects of centre-local relations on planners, how planners executed their duties in a turbulent political environment, and $\mathrm{OM} / \mathrm{RO}$ and the public image of the planning profession.

\section{Research methodology}

The aim of the paper is to explore how politics affects the practice and profession of planning. This paper is based on 20 interviews conducted with practising planners (in government, local authorities and non-governmental organisations [NGOs]), councillors and mayors, and other politicians. These respondents were primarily drawn from five cities namely Bulawayo, Gweru, Harare, Mutare and Masvingo. Table 1 shows the list of people interviewed. Respondents were purposively selected using criteria such as affiliation, role in planning, role in politics, and understanding of the subject matter. The interviews were primarily premised on understanding how politics has affected the profession and practice of planning. In particular, the interviews mainly centred on the effects of contentious 
centre-local relations on planners, executing planning duties in a turbulent political environment and the impacts of $\mathrm{OM} / \mathrm{RO}$ on the planning profession.

The paper mainly focuses on OM/RO, politics of urban control and the FTLRP, largely because, these three constitute the main political issues that comprehensively altered the planning of Zimbabwean cities. These three also led to the problem of the informalisation of planning which changed the form and structure of cities. Whilst the OM/RO was a once-off event, the FTRLP is still ongoing particularly in peri-urban areas. In order to gather data from practical experiences, the authors make sure that most of the respondents were actively involved in planning during and after OM/RO and FTLRP. The key research questions which guided the research were as follows:

a. How does politics affect the practice and profession of planning?

b. What are the political events or programmes which have had an impact on planning?

c. How do planners execute duties in a highly contested political environment?

\section{5. $\quad$ Findings and discussion}

\subsection{Centre-local relations and planners}

By centre-local relations, we refer to the relationship between the national government and urban local authorities. Such relations are defined in law and affected by the prevailing political environment. The Regional Town and Country Planning Act (RTCPA) gives the national government authority to monitor planning standards, the built environment and the overall urban development process (GoZ, 1996). At the same time, local authorities as local planning authorities are mandated with carrying out planning functions in their areas of jurisdiction. In principle, such a relationship bolsters checks and balances in the planning system.

However, post-2000, the rise of the MDC in governing urban areas strained relations between the national government and urban local authorities. Tensions between central and local governments affected the conduct of planning (Muchadenyika, 2015a). For example, the 'FTLRP encroached into peri-urban areas and it became very difficult to implement and monitor town planning as the planning profession was vilified by politicians' (A12). In peri-urban areas, the FTLRP disregarded planning procedures of urban local authorities (see Matondi, 2012). 
Table 1

List of interviewees.

\begin{tabular}{ll}
\hline Name & Description \\
\hline A1 & Government Planner \\
A2 & Former Councillor \\
A3 & Senior Planning Consultant, Zimbabwe Institute of Regional and Urban \\
& Planners (ZIRUP) member \\
A4 & Senior City Planner \\
A5 & Planning School Lecturer \\
A6 & Former Local Government Permanent Secretary \\
A7 & NGO Director/Planner \\
A8 & Planner, ZRUP member \\
A9 & Planning Consultant, ZIRUP member \\
A10 & City Mayor \\
A11 & Harare Resident and Co-operative member \\
A12 & Senior Planning School Lecturer \\
A13 & Senior Government Planner \\
A14 & Planner, Former President-ZIRUP \\
A15 & City Research and Development Planner \\
A16 & City Environmental Planner \\
A17 & Residents Association Director \\
A18 & City Planner \\
A19 & Deputy City Mayor \\
A20 & Government Planning officer \\
\hline
\end{tabular}

Source: Authors' Field Research, 2015.

Town planning principles and foundations were in place but were defeated by politics. In fact, 'ZANU-PF defeated town planning' (A1). The FTLRP brought tension in peri-urban areas affecting land and delivery of planning services. MDC-run urban local authorities saw the programme as a 'strategic attempt to destabilise planning and governance in cities' (A10). Cities were overtaken by a particular form of urban development driven by formal and informal party structures affecting how planning is conducted. In this instance, "planners had no role to play; they were the bonds [as in a chess game], the people sacrificed' (A2). In urban and peri-urban areas, the use of informal institutions and the manner in which the FTLRP took root limited the role of planners to effectively plan cities. Informal institutions performed functions of local authorities, informalised planning and governance and worked against MDC-run local authorities (Kriger, 2012; McGregor, 2013).

The national government has the mandate to deliver some services and plan in cities without the involvement of the local authorities. This is shown in periurban settlements planned and developed by the local government ministry. A 
government planning officer presents planning challenges arising from such an arrangement as:

After 2000, we have seen the government, in particular, the local government ministry increasingly running parallel structures in cities. The ministry has a firm control on the allocation of state land to beneficiaries aligned to the ruling party. This arrangement means that subsequent planning processes are led by the national government though in areas under the jurisdiction of local authorities. It became problematic as urban local authorities challenged the recognition of settlements planned outside their structures (A20).

The change of use provision (Section $35^{1}$ ) in the RTCPA led to most open (recreational) spaces being converted to private and commercial use. However, such change of use in urban areas 'distorted the zoning system' (A3). A city planner in a rather blunt terms argued that 'political players and their cronies exerted pressure for change of use on planners' (A18). Ultimately, most open and often recreational spaces in Harare, Bulawayo, Mutare and Masvingo were converted into private built up spaces. In most instances, change of use benefitted politicians, business moguls and foreign business enterprises. Partly, such changes led to 'the unpopularity of planning and its association with the wealthy and powerful' (Kamete, 2011: 83).

Housing co-operatives formed at the behest of political parties bypassed normal urban planning procedures (Muchadenyika, 2015a). Such co-operatives have also been performing planning functions such as land allocation, layout planning, and approving house construction strategies. In this regard, most settlements are without infrastructure services. Reasons for this structural neglect of planning are twofold: 'one is financial constraints and the second is politicians allowing people to by-pass planning procedures thereby implying development precede infrastructure leading to disorganised urban planning' (A3). Politics associated with land for housing distorts coordinated development planning in cities, for several reasons. First, 'this manifests in numerous unplanned settlements with politicians seemingly having more power than local planning authorities in such areas' (A8). Second, unplanned settlements apparently ensure the longevity of politicians in power and are a guarantor of largesse during the protracted period of financial challenges.

In Senegal, Uganda and South Africa, research indicates that in opposition controlled cities, politics 'become problematic for the delivery of urban services' (Resnick, 2014: s3). In Zimbabwe, the polarisation and contestation between the MDC and ZANU-PF posed severe problems to urban planning. A senior Harare city planner argued that 'contradictions in policy framework between central and local governments made planning extremely difficult' (A4). This is evidenced by the recruitment moratorium placed by the local government ministry on all major 
cities. Under the recruitment moratorium, 'development control and development planning functions were negatively affected' (A4). By December 2011, the City of Harare's Department of Urban Planning Services had 168 vacancies, a condition that weakened the delivery of planning services ( $\mathrm{CoH}$ DUPS, 2012). The moratorium was aimed at 'preventing the MDC councillors from employing loyal party supporters' (A10). City planning departments have been constrained by human resources shortages to carry out development control functions. Subsequently, informal developments sprouted in most urban centres as residents erected structures without plan approval.

When the MDC controlled urban local authorities, ZANU-PF did not accept the reality arguing that it was a regime change strategy. Within three months of MDC mayorship in Harare, most roads had been repaired 'which showed a real grasp of urban issues' (A5). However, in justifying the dismissal of the MDC mayor, the local government minister cited poor service delivery performance. Conversely, Machingauta (2010: 146) argues that 'the impression created by the suspension and subsequent dismissal was that the suspension and subsequent dismissal had nothing to do with service delivery but was meant to frustrate local councils controlled by the opposition political party'. It would seem that, ZANU-PF could not allow progress in an MDC-run council as the success of MDC would deter ZANU-PF's political fortunes. In this instance, the national government had no motivation to improve performance and service delivery by local authorities (Resnick, 2014). After dismissing MDC mayors, central government appointed Commissions to run cities.

During the leadership of appointed Commissions, planners interviewed argued that they could not execute their professional duties according to the standards of town planning practice (A4, A1, A15, A18). In this regard, appointed commissions made planners appendages of political party interests. This is revealed by corrupt procedures during land alienation processes; with ZANU-PF officials as major beneficiaries (City of Harare, 2010).

In view of the corruption, planners were being forced to compromise planning principles in order to meet the requirements of either councillors or the local government minister (City of Harare, 2010). Approval of plans was influenced by politics as 'planners were forced to approve plans quickly, compromising normal planning procedures' (A6). This is evidenced by the widespread mushrooming of residential areas without proper urban planning services. These areas include but are not limited to areas such as Saturday Retreat, Whitecliff, Hopley, Hatcliffe extension among others in Harare and Cowdray Park in Bulawayo. In the aforementioned areas, while layout planning was carried out, people settled without water and sanitation facilities and roads. Thus, people rely on wells, septic tanks and road openings. In addition, the majority of housing structures in those areas are unplanned. Apart from the planned areas, there is an increase 
of unplanned settlements in adjacent areas with land allocated through political structures. Planners might not have wanted the haphazard urban development that took effect but 'political pressure led to the compromise of planning regulations and standards' (A13).

It can be argued that due to mostly political interference; rational, rigorous planning procedures were suspended and 'in the process weakening the planning profession' (A18). Nevertheless, 'problems encountered in cities were far beyond planners as there was disorder in cities' (A7). The informal urban economy has surpassed the formal requirements of planning laws and regulations. In particular, urban poverty in Zimbabwe manifests in ubiquitous informal economic activities and housing (Potts, 2006b; Musoni, 2010). In such a context, the planner was caught in-between vested interests: 'dealing with political vultures and trying to be impartial breeding a crippled planner' (A4). However, the presence of planners in both central government (Department of Physical Planning) and urban local authorities somehow limited the negative impacts of the competing centre-local relations to planners. This is, however, not to deny that there is tension between planners in central government and those in urban local authorities. We argue that such tensions seem to emanate from different loyalties and allegiances-a veritable battleground during fiscal constraints, social discontent, and turbulent politics.

\subsection{Planners and turbulent politics}

As indicated at the outset of this paper, planning is in politics, cannot escape politics and the role of planners is, indeed, highly political (Albrechts, 2003). It is, therefore, important, to understand, contextually, how political tensions affect planners. The political environment in which the planner operated was contested and confusing (A1). The consolidated voice of professionals at higher levels became critical. In this context, the image and integrity of planning needed strong defence from a vibrant professional association. However, the Zimbabwe Institute of Regional and Urban Planners (ZIRUP) 'failed to bring to the attention of the local government ministry issues affecting the planner' (A8). The collective voice of planners in a more systematic way was weak complicating the planners' work. It should however be noted that ZIRUP is a voluntary association not backed by any law. Partly, this explains the weakness of ZIRUP as a professional association.

Watson (2014: 118) argues that planners should uphold professional ethics that is 'professional conduct' and 'the nature of the planning process and its outcomes'. The representation of a consolidated voice of planners is vital in defending professionals and the integrity of the profession. However, since its formation in the early 1980s, 'ZIRUP has struggled to become a respectable professional body even amongst planners themselves' (A12). Planning as a practice has also changed, with planners working in civil society and non-governmental organisations, international development agencies, local authorities and 
government. However, the flagship ZIRUP annual school has not transformed itself to depict the changing reality in which the majority of planners are working in. Further, 'the body has not stood firm in defending attacks on the profession and planners' (A14). Rather, leaders of ZIRUP have largely succumbed to politics; a development which irks ordinary people. This has, however, dented the image and credibility of the profession in the eyes of the general public.

Urban planning has two sides; forward planning and development control. Forward planning, that is, master and local planning suffered due to insufficient resources and political turbulence as 'all statutory plans in use in Zimbabwe are out of time' (A9). Development control activities such as enforcing regulations, approval of plans, transport and vender management suffered as the economy turned informal. It was therefore not possible to enforce using planning regulations prepared in a normal economy' (A1). In such an environment, planning became nearly impossible emphasising ad hoc issues, and reactive as opposed to futuristic forward planning. In most cities, 'transport management became a de facto responsibility of ZANU-PF youth who went as far as collecting fees from commuter operators' (A18). It is widely believed that such forms of extortion were organised and worked under the direction of senior politicians.

The calibre of mayors is a critical element determining how planners execute their duties in a turbulent political environment. For the City of Harare, city planners interviewed applauded Mayor Masunda (2008-13) for being dynamic, apolitical, and his tremendous role in assisting the work of planners (A4). For instance, the Mayor played an instrumental role in the Bill and Melinda Gates Foundation project which strengthened and capacitated the City of Harare's urban planning department with information communication technologies and geographic information systems (GIS) (Muchadenyika, 2015b). The department had been struggling to acquire GIS equipment and the city was having difficulties in funding the initial capital (A2). Due to the Gates Foundation project, the urban planning department is in a position 'to produce accurate and up-to-date urban planning maps and data which inform decision making consequently helping in service delivery' (A4). Further, the City's survey department is now able to contract out, 'due to capitalisation from the Gates Foundation project, whose compliments can be attributed to the City mayor' (A4).

The division of labour between politicians and planners was blurred. There exist duplication of roles and responsibilities between planners and politicians. For instance, a city planner highlighted that:

Planning is the responsibility of planners. However, we are having situations where politicians are coming to us sometimes with already prepared layout plans. They are dictating to us to put land uses where they want without any planning rationality. Are we still planners then? Are politicians now the new planners? 
Politicians must handle political and governance issues while we handle technical aspects such as planning (A18).

In addition, there were struggles between planners and young people in cities (A4). Young people with 'protection from political parties invaded most urban spaces' (A17). Political party youth wings occupied and used open places illegally. In such situations, planners could not act as professional interlocutors as young people were a mere front of politicians and in many instances, with the state backing.

Allegiance and patronage affected the recruitment of chief city planners as illustrated by the following example. The Chief City planners were 'purely political posts, thus, candidates were vetted over political affiliation' (A4). In this regard, planners had to ensure a balance between appeasing the appointing authority and planning rationality. Indeed, it would seem that the obvious looser became the latter. What this example illustrates is that planning is an intricate process, profoundly influenced, if not shaped by adversarial political processes. Invariably, planning has not been devoid of political interference and meddling, as the discussion on $\mathrm{OM} / \mathrm{RO}$ here below indicates.

\subsection{Operation Murambatsvina and the planning profession}

Whilst the Government of Zimbabwe has tried to portray the objectives of OM/RO as purely planning based (GoZ, 2005), evidence suggests to both political and planning motivations (Bratton \& Masunungure, 2006; Bracking, 2005). Disorganised urban planning resulted in the infamous OM/RO of 2005. However, it should be noted that 'such disorganisation was a creation of collusion between politicians and planners to achieve goals of the former' (A1). This view is corroborated by Chipungu and Adebayo (2012) who points to the undue party political influence on the process of planning. For instance, the role of politics during the Operation is demonstrated in the case of the local government minister who officiated at Joshua Nkomo housing co-operative which was later destroyed during the Operation. Upon the destruction of co-operative houses, the minister argued 'if you invite me to your wedding I will come but I cannot know that you are wedding someone's wife!' (A11). Politically aligned co-operatives are at the centre of pursuing a parallel planning system in cities. Such co-operatives provide a platform for political organisation within the urban environs with access to land traded for political participation and allegiance.

Party politics resulted in the problem of overcrowding and informal settlements in cities; with party structures performing de facto urban planning functions. In such a context, planners and other urban development professionals were constrained (A15). Prior to the Operation, the form and structure of cities had significantly changed as if 'there was no planning at all' (A14). The preamble of the Regional Town and Country Planning Act states the objectives of town planning. 
Among them is protecting the physical environment, which was a key deliverable for Operation Murambatsvina, one can argue. Prior to the Operation, there was wanton destruction of the physical environment exposing communities to health and natural hazards (A16). A senior Harare city planner argued that the United Nations Special Envoy was a 'traitor' as she appeased her paymasters instead of the welfare of the people-a challenge that planners face' (A4).

The impact of OM/RO exposed planning as a profession in contestation. OM/RO resembles the failure of planning, one can argue. Planning had 'failed to respond to challenges it was supposed to address' (A7). If planning served its purpose, it would have planned and handled OM/RO in a professional manner and there would be no need for another Operation. In reality, planning principles to address informality were superseded by politics. On the other hand, 'the government's housing destruction during $\mathrm{OM} / \mathrm{RO}$ emphasised the essence of planning, which can be understood as the supremacy of planning' (A18). Consequently a senior planner argued that ' $\mathrm{OM} / \mathrm{RO}$ was the best thing that happened to planners as all of a sudden planning was elevated though planners did not capitalise on the programme' (A8). However, gradually, things reverted to pre-OM/RO with planning and planners becoming somewhat 'irrelevant'.

On the other hand, planning did not enforce OM/RO as a policy, though planning laws and regulations were used. Planning was very insensitive and unreasonable to the public eye 'though Zimbabweans remember OM/RO not much about planners, but the brutality of Robert Mugabe and his regime' (A12). During OM/RO the violence was systematic and targeted at areas where the opposition MDC garnered majority votes (Bracking, 2005). In this instance, ZANU-PF thought that the 'people who voted for MDC were mainly residing in unplanned settlements' (A6). The plan was to send MDC supporters to rural areas under the control of traditional chiefs who are often loyal to ZANU-PF (A17). However, 'with time, it emerged that OM/RO political motivations were bigger than planning motivations' (Muchadenyika, 2015b: 3). It is in such political struggles in which the planning profession is often entangled, frequently undermining the credibility of the profession.

During OM/RO, expensive housing structures were destroyed in the name of planning. The Operation also destroyed many home industries which were a livelihood source for the majority of urban residents (Jones, 2010). This made planning to people not a humane, sensitive profession to assist them but a 'dictatorial, and demagogue profession to make people's lives difficult' (A6). Yet, that is not the intention of planning. As such, planning is viewed with scepticism as a profession out to find and punish culprits (A17). Even the United Nations Special Envoy Report did not exonerate planners; rather, it attacked planning law and regulations. Kamete (2009) argues that planning deserves blame during the Operation. This is mainly because, illegal settlements sprouted in the presence of planners and 'only to turn against these settlements when ZANU-PF lost support in 
cities' (A12). In this case, planning became a useful tool to achieve political objectives of the ruling regime.

Judging from $\mathrm{OM} / \mathrm{RO}$ and the aftermath, planners are 'not considered important by both the public and government' (A2). As such, the profession of planning has little merit in Zimbabwe. This is exacerbated by the absence of a vibrant professional planning association (A14). It can, however, be argued that the future of planning in the country rests on the country shifting from predatory to inclusive politics. The process of 'plan preparation, application for planning permit and approval has institutionalised corruption' (A13). Such rent seeking behaviour in the profession damaged the image of the profession. Corruption is exacerbated by the fact that the profession is unregulated and hence, there are no penalties for professional misconduct. It can be argued that the planning system has remained intact, though corruption has deeply infiltrated it.

Planning, as a profession, is not regulated in Zimbabwe. As such, anyone can practice planning-a situation which makes it difficult to regulate planning practice. Such 'non-regulation significantly accounts why we ended up having Operation Murambatsvina' (A13). Government, however, regulates other professions in the built environment such as engineering, surveying and architecture. The non-regulation of planning as a profession can be interpreted as government placing little value and respect on planning. The apparent lack of order that obtains in Zimbabwe's urban areas which has transgressed planning principles, can in part, be attributed to an unregulated profession. An unregulated profession 'seems to become instrumental in political manipulation and advancing political interests' (A10).

Indeed, during $\mathrm{OM} / \mathrm{RO}$, planners and the professional body failed to bring to light the government excesses in using and abusing planning laws and regulations to crush what people had built for years. Regrettably, there is evidence to suggest that some of the houses demolished were formally planned, and approved or regularised (Nhekairo, 2012). It is such cases to which planners should have drawn attention and defended. In other words, 'planners failed to identify themselves with their work' (A15). A senior planner asked: 'how do people view the profession of planning in cases where formally planned and approved houses were demolished? I think one is quick to associate planning with confusion and lack of integrity and ethics' (A13).

The impacts of $\mathrm{OM} / \mathrm{RO}$ notwithstanding, it can be argued that the planning profession had long lost credibility during the ESAP period (1990-95). During this period, planning was criticised by groups like the 'Affirmative Action Group, Indigenous Groups, and the National Economic Planning Commission making spatial planning a nuisance' (A12). Indigenisation and affirmative action had a tendency to flout urban planning laws as city leaders colluded with business 
interests (Dawson \& Kelsall, 2012). It can be argued that the cumulative impact of $\mathrm{OM} / \mathrm{RO}$, indigenisation, land reform and affirmative action, four structural interventions resulted in politics overriding planning and the indirect acceptance of informal planning systems.

$\mathrm{OM} / \mathrm{RO}$ had substantial repercussions on planning as a profession. The reputation of planning as a profession was severely compromised during and after Operation Murambatsvina (Kamete, 2007). This is exacerbated by the country's failure to embark on reform of planning systems. Moreover, the United Nations Special Envoy Report described the Regional Town and Country Planning Act as 'outdated' and in need of immediate revision. Three years after OM/RO, the government-led second National Housing Convention castigated town planning standards as 'very high, very elaborate, rigid [...] and not responsive to the needs and requirements of the end users' (GoZ, 2009: ix). However, such observation is yet to translate into the actual revision of planning laws and standards.

Using three settlements in Harare affected by OM/RO, we argue that many demolished areas were reinvaded and that the Operation led to new informal settlements. For example, in Dzivarasekwa Extension, informal settlers reinvaded the area without planning and infrastructure services. However, the Harare Slum Upgrading Programme (2010-15) provided planning and infrastructure services and secure tenure to 480 households on the reinvaded settlement (see Muchadenyika, 2015b). In Saturday Retreat, government demolished the settlement during OM/RO. However, despite producing a layout plan and surveying of stands, a significant portion of the area has been settled informally. Informal settlers evicted from different parts of Harare in 2005 settled informally in Caledonia. The settlement grew organically, though without planning and infrastructure services. In fact, only phases 1-3 (6960 residential stands) had an approved layout plan while phases 4-20 (15,450 stands) has no approved plan (MLGPWNH, 2015). Caledonia is home to about 115,000 people making it perhaps the largest informal settlement within City of Harare boundaries. However, in 2015, government through the Urban Development Corporation began a process of regularising the settlement. The regularisation approved layout plans for phases 4-20 and 'regularised 27,000 houses with about 90\% of the structures being completed houses' (A2O). The regularisation process was government-directed and bypassed the City of Harare though it is the local planning authority. This shows 'the tensions associated with planning in which the national government usurps local authority functions in a bid to meet political objectives of the ruling party' (A19). Caledonia is an important constituency for ZANU-PF in Harare.

Based on the above, OM/RO did not resolve the challenge of informal settlements. Rather, it shifted the geography of such settlements with government failing to provide services in both formal and informal settlements. A study by the City of Harare profiled and enumerated 62 slums within Harare in 2014 (City of Harare, 
Dialogue on Shelter and Zimbabwe Homeless Peoples Federation, 2014). It can therefore be argued that government did not 'restore order' in peri-urban areas. Rather, a new wave of militant illegality emerged in urban areas largely driven by politics. The aftermath of OM/RO had 'a huge strain on planning as militant movements reversed the procurement process of formal housing' (A15). Post2000, the image of the planning profession suffered significantly during the era of impunity which spilled into urban planning. The informal structure of cities stands as an empirical record of such forms of disorganised planning. In its bid to reclaim the urban constituency; ZANU-PF 'forced councillors and councils to turn a blind eye into disorganised urban planning' (A10). Unplanned and informal settlements sprouted. Such partisan political elements affected town planning, with planners becoming, seemingly largely powerless. Thus, the efficacy of planning as a profession was and is still being questioned.

\section{Conclusion}

The evidence of political interference marshalled in this paper, also suggests that the profession of planning, in the midst of political contestation, has severely undermined planning and its contribution towards organised cities. Planners succumbed to politics of patronage at the expense of urban residents and town planning principles. Simply put, the ZANU-PF government defeated the intentions of town planning as planning laws and regulations only applied where the party had no interests. Partly, the failure of planning manifested in the infamous Operation Murambatsvina, which displaced millions of people. The national government used and abused town planning laws and regulations to back a hasty and insincere Operation Restore Order. In a way, the Operation exposed planning with the efficacy of the profession questioned. Planners interviewed indicated that the profession of planning is weak, under siege from politicians and confused.

Perhaps, the central argument of the paper is that planning is distorted by contested politics. In such instances, developing sustainable cities becomes a deferred reality. As such, the integrity of the profession and practice of planning is fundamental in attaining SDG 11. In that vein, the role of planners and planning should be mainstreamed in the development agenda through sustained, grassroots-driven contestation and engagement with local authorities.

Managing the process of urbanisation requires a strong and vibrant planning profession to handle overarching issues and inherent conflicts. Since widespread disorder seems to prevail in the Zimbabwean built environment, we recommend that the planning profession be regulated and provide the minimum ethical standards for the development of cities. In this regard, the planning professional body ZIRUP should be legally recognised and mandated with functions such as registration, monitoring and evaluation of professional planners. 


\section{References}

Albrechts, L. (2003). Reconstruction decision-making: Planning versus politics. Planning Theory, 2(3), 249-268.

Allum, P. (2003). The politics of town planning in post-war Naples. Journal of Modern Italian Studies, 8(4), 500-527.

Anderson, E. J., Jenkins, P., \& Nielsen, M. (2015). Who plans the African city? A case study of Maputo: Part 1-The structural context. International Development Planning Review, 37(3), 329-350.

Bracking, S. (2005). Development denied: Autocratic militarism in postelection Zimbabwe. Review of African Political Economy, 32(104/105), 341-357.

Bratton, M., \& Masunungure, E. (2006). Popular reactions to state repression: Operation Murambatsvina in Zimbabwe. African Affairs, 106(422), 21-45.

Campbell, H. (2001). Planners and politicians: The pivotal planning relationship? Planning Theory \& Practice, 2(1), 83-85.

Castells, M. (2012). Networks of outrage and hope: Social movements in the internet age. Cambridge: Polity Press.

Chipungu, L., \& Adebayo, A. A. (2012). The policy-planning divide: An evaluation of housing production in the aftermath of operation Murambatsvina in Zimbabwe. Journal of Housing and the Built Environment, 28, 381-396.

City of Harare (2010). Special investigations committee's report on city of Harare's land sales, leases and exchanges from the period October 2004 to December 2009. (Report present- ed by Councillor W. Dumba (Chairperson of the Special Committee) on 23 March 2010).

City of Harare, Dialogue on Shelter and Zimbabwe Homeless Peoples Federation (2014). Harare slum upgrading profile report. Harare: Dialogue on Shelter and City of Harare.

COH DUPS (2012). Department of urban planning services annual report 2011. Harare: City of Harare Department of Urban Planning Services.

Crawford, J. (2009). Values, networking and the hybrid planner. Planning Theory \& Practice, 10(2), 161-164.

Dawson, M., \& Kelsall, T. (2012). Anti-developmental patrimonialism in Zimbabwe. Journal of Contemporary African Studies, 30(1), 49-66.

Dredge, D., \& Coiacetto, E. (2006). Planning as a career choice: First year students' knowledge of and attitudes towards planning. Australian Planner, 43, 26-36.

Dreyfus, H. L., \& Rabinow, P. (1983). Michel Foucault: Beyond structuralism and hermeneutics (2nd ed.). Chicago: University of Chicago Press.

Fenster, T. (2004). Belonging, memory and the politics of planning in Israel. Social \& Cultural Geography, 5(3), 403-417.

Flyvbjerg, B. (1998). Rationality and power: Democracy in practice. Chicago: University of Chicago Press.

Forester, J. (1989). Planning in the face of power. Berkeley: University of California Press. 
Foucault, M. (1983). The subject and power. In H. S. Dreyfus, \& P. Rabinow (Eds.), Michel Foucault: Beyond structuralism and hermeneutics (pp. 208226). Chicago: University Chicago Press.

GoZ (1994). Regional, town and country planning (use groups) regulations, 1994: Statutory instrument 216 of 1994. Harare: Government Printers.

GoZ (1996). Regional Town And Country Planning Act, chapter 29:12. Harare: Government Printers.

GoZ (2005). Response by the government of Zimbabwe to the report by the UN special envoy on operation Murambatsvina. Harare: Government of Zimbabwe.

GoZ (2009). Second national housing convention report. Harare: Ministry of National Housing and Social Amenities.

Healey, P. (2004). The treatment of space and place in the new strategic spatial planning in Europe. International Journal of Urban and Regional Research, 28(1), 45-67.

Iveson, K. (2000). Beyond designer diversity: Planners, public space and a critical politics of difference. Urban Policy and Research, 18(2), 219-238.

Jenkins, P. (2013). Urbanization, urbanism, and urbanity in an African city: Home spaces and house cultures. New York: Palgrave.

Jones, J. L. (2010). 'Nothing is straight in Zimbabwe': The rise of the Kukiya-kiya economy 2000-2008. Journal of Southern African Studies, 36(2), 285299.

Kamete, A. Y. (2004). Home industries and the formal city in Harare, Zimbabwe. In T. H. Hansen, \& M. Vaa (Eds.), Reconsidering informality: Perspectives from Urban Africa (pp. 120-138). Uppsala: Nordiska Afrikainstitutet.

Kamete, A. Y. (2006). The return of the jettisoned: ZANU-PF's crack at 'reurbanizing' in Harare. Journal of Southern African Studies, 32(2), 255-271.

Kamete, A. Y. (2007). Cold-hearted, negligent and spineless? Planning, planners and the (r)ejection of "filth" in urban Zimbabwe. International Planning Studies, 12(2), 153-171.

Kamete, A. Y. (2009). In the service of tyranny: Debating the role of planning in Zimbabwe's urban 'clean-up' operation. Urban Studies, 46(4), 897-922.

Kamete, A. Y. (2011). Interrogating planning's power in an African city: Time for reorientation? Planning Theory, 11(1), 66-88.

Kriger, N. (2012). ZANU PF politics under Zimbabwe's 'power-sharing' government. Journal of Contemporary African Studies, 30(1), 11-26.

Krumholz, N. (2001). Planners and politicians: A commentary based on experience from the United States. Planning Theory \& Practice, 2(1), 96100.

Machingauta, N. (2010). Supervision of local government. In J. de Visser, N. Steytler, \& N. Machingauta (Eds.), Local government reform in Zimbabwe: A policy dialogue (pp. 139-150). Cape Town: University of Western Cape, Community Law Centre. 
Marongwe, N. (2011). Who was allocated fast track land, and what did they do with it? Selection of A2 farmers in Goromonzi District, Zimbabwe and its impacts on agricultural production. Journal of Peasant Studies, 38(5), 1069-1092.

Matondi, P. B. (2012). Zimbabwe's fast track land reform. Uppsala, London, and New York: NordiskaAfrikainstitutet and Zed Books.

McGranahan, G., Schensul, D., \& Singh, G. (2016). Inclusive urbanization: Can the 2030 agenda be delivered without it? Environment \& Urbanization, $28(1), 13-34$.

McGregor, J. (2013). Surveillance and the city: Patronage, power-sharing and the politics of urban control in Zimbabwe. Journal of Southern African Studies, 39(4), 783-805.

Miller, E., Sahama, T., Grace, P., Wilson, C., \& Hefferan, M. (2011). Motivations, expectations and experiences of Australian rural and regional planners. Australian Planner, 48(4), 305-312.

MLGPWNH (2015). Report on the findings of the inter-ministerial team investigating issues at Caledonia Farm. Harare: Ministry of Local Government, Public Works, and National Housing.

Muchadenyika, D. (2015a). Land for housing: A political resource-Reflections from Zimbabwe's urban areas. Journal of Southern African Studies, 41(6), 1219-1238.

Muchadenyika, D. (2015b). Slum upgrading and inclusive municipal governance in Harare, Zimbabwe: New perspectives of the urban poor. Habitat International, 48, 1-10.

Muchadenyika, D., \& Williams, J. J. (2016). Social change: Urban governance and urbanization in Zimbabwe. Urban Forum, 27, 253-274.

Musoni, F. (2010). Operation Murambatsvina and the politics of street vendors in Zimbabwe. Journal of Southern African Studies, 36(2), 301317.

Nhekairo, A. (2012). The effects of operation Murambatsvina and operation Garikai/Hlalani Kuhle on urban local authorities and their residents. In K. Chatiza (Ed.), Urban housing and community services delivery in Zimbabwe: A compendium of selected papers presented at housing directors' forum meetings (pp. 25-28). Harare: UN-Habitat, UCAZ and SIDA.

Potts, D. (2006a). Urban growth and urban economies in Eastern and Southern Africa: Trends and prospects. In F. D. Bryceson, \& D. Potts (Eds.), African urban economies viability, vitality or vitiation? (pp. 67106). Hampshire and New York: Palgrave.

Potts, D. (2006b). 'Restoring order'? Operation Murambatsvina and the urban crisis in Zimbabwe. Journal of Southern African Studies, 32(2), 273-291. 
Potts, D. (2011). 'We have a tiger by the tail': Continuities and discontinuities in Zimbabwean city planning and politics. Critical African Studies, 4(6), 15-46.

Resnick, D. (2014). Urban governance and service delivery in African cities: The role of politics and policies. Development Policy Review, 32(S1), s3-s17.

Sandercock, L. (1997). The planner tamed. Australian Planner, 34(2), 90-95.

UN (2016). The sustainable development goals report 2016. New York: United Nations.

UN-Habitat (2009). Global report on human settlements 2009: Planning sustainable cities. Nairobi: UN-Habitat.

United Nations (2005). Report of the fact-find mission to Zimbabwe to access the scope and impact of operation Murambatsvina by the United Nations special envoy on human settlement issues in Zimbabwe. Nairobi: United Nations.

Walsh, C. (2014). Rethinking the spatiality of spatial planning: Methodological territorialism and metageographies. European Planning Studies, 22(2), 306-322. Watson, V. (2014). Will the profession speak out? Winners and losers in the future African city. Planning Theory \& Practice, 15(1), 115-118.

Williams, J. J. (2000). South Africa: Urban transformation. Cities, 17(3), 167183. 